\title{
Management Model of Character Education Development in High Education through Dormitory
}

\author{
A Case study on first-grade students at University X \\ M. Yahya Arwiyah*, Runik Machfiroh, Djoko M, A.M.A. Suyanto \\ Business Administration, Creative Industry, Management \\ Telkom University \\ Indonesia \\ *yahya@telkomuniversity.ac.id
}

\begin{abstract}
Character education which has not become a culture yet is a pattern of behaviors and ways of acting that have been automatically formed into a living part of an educational community. This research aims to obtain a real picture and analysis of the management model of character education development in students through the dormitory at University $X$. The research method used in this case study is a qualitative approach. The management model of Character education in college can be integrated with organizational culture together with all of the curricular activities, extracurricular and life culture in dormitories that complement each other with five basic values defined as values of the university and become character development orientation.
\end{abstract}

Keywords — character education; higher education; dormitory

\section{INTRODUCTION}

Education plays an important role in human development and civilization. One of government policy in developing the ability and forming the character of a civilization is by character education. Although character education has been done through different ways and methods at every level of education, in reality, education has not been able to produce graduates who have a superior character.

The importance of investing good character values by means of education has become a concern in the education system in Indonesia. The founders of the nation, especially the educational figures who pioneered the development of the education system since the colonial era until the independence period, has designed an educational curriculum that focuses on moral education, then called "character education".

Lately, the Government is also aware of the benefits of character education, by strengthening with the implementation of the Curriculum 2013, which emphasizes the formation of attitudes, knowledge, and skills in a balanced way. Curriculum 2013 aims to prepare Indonesian people to have the ability to live as individuals and citizens who have faith, productive, creative, innovative, and able to contribute to the life of society, nation, state, and civilization of the world. But it is unfortunate that this lofty ideal stalled by postponed or reevaluated the implementation of the 2013 curriculum in the year 2104 ago until now. In the long-term character education in Indonesia has been incorporated in the National Character Building Policy of the Year 2010-2025. The policy stipulates that character education is conducted in an integrated way through the learning of various subjects contained in the curriculum, extra-curricular activities and the development of campus/school culture.

There are at least three assumptions that the integration of the character education process in Indonesia has not gone well. First, from the initial observation that the content of subjects related to character education in universities is still low, namely civic, religion, entrepreneurship, and Indonesian literature, with a course number of about 8 credits or 5 percent of total credits of undergraduate education. In addition, learning is still paying more attention to aspects of cognitive and psychomotor rather than its effectiveness.

Extracurricular activities have not been directed to the formation of student characters. The activities of educational units that are general and not directly related to a subject, such as Student activity units (Red Cross, Nature Activities, Design Community, and Region Community) have not yet developed the process of habituation and reinforcement in character development.

Character education has not become a culture yet is a pattern of behaviors and ways of acting that have been formed automatically become a living part of an educational community. Basic patterns of behavior and how to behave is arranged by social norms, regulations, and education policy. The important issue is how to make these noble characters become a culture or habit, especially for students [1]. A good school/campus culture will deliver the best performance for individuals, community, and school as an institution. Various researches related to character education has been done through school, community, and internet which generate a strategic way to execute character education [2,3]. School/campus cultures are expected to improve the quality and performance of the school so the quality of life can be healthy, dynamic or active, positive and professional. However, this article will focus on character education in colleges through dormitories with organizational culture as a basic value in a college organization. 
The results of research [4] found that students living in dormitories in Private University X can raise legal awareness. However, for the cultivation and internalization of other character values need to be further investigated. In this research will explain about how is Private University $\mathrm{X}$ develop the five values of organizational culture oriented to form the character of students, namely Professionalism, Recognition of Achievement (Integrity), Mutual Respect (Togetherness) and Entrepreneurship through dormitory and academic and extracurricular, which is used as reference attitude, behavior in work by all stakeholders such as staff/officer, lecturer, and student. If the entire academic community adheres to and uses the values of the organization as a culture in the work life, then productivity and creativity will increase.

Organizational culture in a good college will provide opportunities for all civitas to function optimally, work efficiently, have a high spirit and will be able to grow continuously. The problem is that it is not easy to ensure all stakeholders to consistently work based on the agreed cultural values. Therefore, this study is concerned to know what kind of the management model in developing character education from organizational culture.

\section{ReSEARCh Methodology}

The method used in this study is a case study to get a real picture of the development of character education on students through the culture of college organizations in Private University that have a PRIME cultural value. In this research, analyzing character education management model at college through dormitory can be integrated with organizational culture together with all curricular activity, extracurricular and the dormitory life which is complementary with five basic values which are defined as values of the university and become character development orientation.

The subjects of the study consisted of persons who were assessed to provide some of the information required in the study. Determination of research subjects conducted purposively based on the needs of research. The subjects in this research consist of Vice Rector I Academic Affairs, Dean, Vice Dean of Academic, Head of Department, Civic Lecturer, Religion Lecturer, Director of Student Affairs, Dormitory Manager, Director of Career Development Center (CDC), and student with data collection techniques of interviews, documentation and observation, and data triangulation to obtain validity of data. The analysis of qualitative research data includes data reduction, display data, and withdrawal of conclusions.

\section{RESUlt AND DISCUSSION}

The development of character education through dormitories by developing the values of organizational culture in Private University $\mathrm{X}$ is the result of rational thought from the stakeholders involved in the formation of Private University X. College is a means of values and personality culture, academic quality development, and professional development based on the field of science with cognitive nuances. Education is believed to be able to form whole human beings in all dimensions of life that are capable of considering the progress and changing times.

A character is an important thing to be developed because it is a factor supporting one's success in carrying out daily activities. The character occupies the most important part for the survival of human life in society because the quality of human resources has a higher position than the natural resources and is often referred to as a determinant of the national prosperity.

Private University $\mathrm{X}$ always strives to develop character education in every dimension. The dormitory is one of the alternative media of cultivating the value especially the legal awareness in universities [4]. This becomes essential referred to the reaction of decreasing morality of the millennial generation. Besides the development of globalization era demanding every citizen to be able to compete in the competitive climate, it implies the need to develop an educational format of creating a globalized graduate who keeps maintaining the values of the national identity.

The development of anthropological (cultural) approach becomes important to support the achievement of the quality development of citizens. In this case, culture stimulates one to think visionary and far-sighted. Recommendations from Murdowo suggests that there should be research related to management model character education in the dormitory. Besides that, Murdowo also state that character education through dorms becomes an alternative policy in the values development. Associated with the previous argumentations, Private University $\mathrm{X}$ always uses a cultural approach to implementing character education for its students through the approach of organizational culture [5].

Private University has a specific orientation in terms of character and personality development of students, which refers to the five basic values that become the basics of telecommunication companies, including Professional, Recognition of achievement, Integrity, Mutual Respect, Entrepreneurship called PRIME. These five substance characters developed are the embodiment of Private University's vision, mission, and goals. Based on the previous research conducted through interviews, documentation studies, observations and some references, the research team classified the five values into a more specific framework shown in table 1 . 
TABLE I. CULTURAL VALUES OF ORGANIZATIONS IN PRIVATE UNIVERSITY

\begin{tabular}{|c|c|c|c|}
\hline No & Value & Key Behaviour & Description \\
\hline 1 & Professionalism & $\begin{array}{l}\text { Quality of product and service } \\
\text { Perfection in work } \\
\text { Customer delight } \\
\text { Continues Improvement } \\
\text { Decisiveness (in solving problems, planning, } \\
\text { executing plans, in terms of speed and } \\
\text { commitment to decisions once made) }\end{array}$ & $\begin{array}{l}\text { The ability of the Academician of Private University to carry out } \\
\text { the role based on the demands of job competence. Professionalism } \\
\text { is demonstrated by the ability to utilize science, skills, and attitudes } \\
\text { in completing every job and duties with the best quality for } \\
\text { themselves and the environment. }\end{array}$ \\
\hline 2 & $\begin{array}{l}\text { Recocnition of } \\
\text { Achievement }\end{array}$ & $\begin{array}{l}\text { Quality of product and service } \\
\text { Perfection in work } \\
\text { Customer delight } \\
\text { Continues Improvement } \\
\text { Decisiveness (in solving problems, planning, } \\
\text { executing plans, in terms of speed and } \\
\text { commitment to decisions once made) }\end{array}$ & $\begin{array}{l}\text { The sincerity of Private University academia to acknowledge and } \\
\text { appreciate the work of others can be shown by giving appreciation } \\
\text { in the form of speech, attention, attitude or another act of } \\
\text { appreciation. The initiative of Private University academia will } \\
\text { produce positive achievement. }\end{array}$ \\
\hline 3 & Integrity & $\begin{array}{l}\text { Commitment } \\
\text { Honesty } \\
\text { Opennes } \\
\text { Responsibility } \\
\text { Loyalty }\end{array}$ & $\begin{array}{l}\text { Self-attitude and positive relationships with fellow employees, } \\
\text { students, and all stakeholders such as honest, trustworthy, } \\
\text { independent, obedient and telling the truth. }\end{array}$ \\
\hline 4 & Mutual Respect & $\begin{array}{l}\text { Goodness } \\
\text { Trust } \\
\text { Harmony } \\
\text { Cooperation } \\
\text { Tolerance } \\
\end{array}$ & $\begin{array}{l}\text { Build Private University with the principle of cooperation, justice, } \\
\text { respect the differences, build togetherness, harmony and develop } \\
\text { positive values of individuals and organizations towards the } \\
\text { achievement of the institutional vision. }\end{array}$ \\
\hline 5 & Entrepreneurship & $\begin{array}{l}\text { Creativity } \\
\text { Innovation } \\
\text { Decision Making } \\
\text { Taking Risk (calculated risk) } \\
\text { Initiative }\end{array}$ & $\begin{array}{l}\text { The ability to create productive activities that are beneficial for } \\
\text { improving the welfare and scientific competence of lecturers and } \\
\text { students and having a marketing spirit to attract prospective } \\
\text { students, industry and the general public. }\end{array}$ \\
\hline
\end{tabular}

Table 1 explained that professionalism and work acknowledgment did by prioritizing the product quality and services, finishing the job perfectly, striving to be a good customer (public service), making improvements to solve problem constantly, planning and executing a plan properly.

The integrity is characterized by the commitment, honesty, openness, responsibility, and loyalty to the given job and position. The respect consists of a number of values of goodness such as trust, harmony, cooperation, and tolerance, the basic values that must be possessed by every human being who will live, grow and develop in the world of work. Entrepreneurship is creating the students to have creativity, innovation, able to make decisions, take risks and have the initiative.

All of these positive values have a number of obstacles and challenges, but Private University continues to move so that these five basic values become the character of the Private University graduate students. Based on the conducted research, researchers can find that the character education model implemented in Private University at least done through three domains, namely curricular domain, extracurricular domain and dormitory culture domain.
The three domains are consistent to the grand design of character education that explains the micro characters development divided into four pillars, namely teaching and learning activities in the classroom, daily activities in formal and non-formal education, formal and/or extracurricular activities, and daily activities at home and community. The difference is character development in Private University is also done through daily activities in the dormitory. The dormitories are positioned as one of the character building for new students.

Based on the analysis and study of the research result, the researchers create a conceptual scheme of character education development through organizational culture in Private University as can be seen in figure 1 .

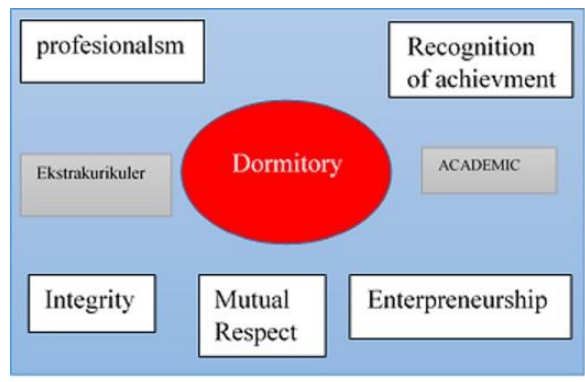

Fig. 1. Conceptual scheme of character education development through organizational culture in Private University. 
Figure 1 illustrates 6 values of university become management model of character education in Private University $\mathrm{X}$. There is a specific management in dormitories integrated with the academic value development and extracurricular which becomes a student obligation on a campus. In addition, there is a special management for final year students to evaluate the character development during the dormitory and to prepare the workplace life. This means the management of character education in the dormitory in Private University $\mathrm{X}$ becomes the initial of character development of the nation.

\section{CONCLUSION}

Character education management model at University through dormitory can be integrated with organizational culture in University by implemented with all curricular activities, extracurricular and life culture in dormitories that complement each other with five basic values which set as values of University and become character development orientation.

\section{REFERENCES}

[1] Marzuki, "Revitalisasi Pendidikan Agama di Sekolah dalam Pembangunan Karakter Bangsa di Masa Depan." Jurnal Pendidikan Karakter, 2013.

[2] Dahliyana. A, Habituasi Pendidikan Karakter di Sekolah melalui Kegiatan Ekstrakurikuler, Acta Civicus, vol. 2, no. 2, April 2012.

[3] Sofyan, E. Penggunaan Internet Dengan Motif Kreatif Dan Motif Hiburan Berpengaruh Terhadap Karakter Peserta Didik.Acta Civicus, vol.2, no. 2, April 2012.

[4] Arwiyah. M Y and Machfiroh R, Analysis of Legal Awareness of The First Students (Case Study on Students' Dormitory at the University of X). "International Journal of Economic Research (IJER)" vol. 13, issue. 9, IJER is Scopus indexed journal, 2016.

[5] Murdowo dkk, Student Dormitory As A Character-Based Education In Higher Schools, (A Case Study At Telkom University Dormitory Bandung).International Journal of Humanities and Social Science, vol. 7 ,no. 12, Desember 2017. 